\title{
Does Anxiety Affect the Anesthesia Type Chosen by Cesarean Section Patients?
}

\section{Anksiyete Sezaryen Hastaları Tarafından Seçilen Anestezi Tipini Etkiler mi?}

\author{
Hakan Tapar \\ Tokat Gaziosmanpasa University School of Medicine Department of Anesthesiology and Reanimation, Tokat, Turkey
}

\begin{abstract}
Aim: The maternal anxiety associated with cesarean delivery is important issue. We aimed to assess whether the preoperative anxiety level of obstetric patients undergoing an elective caesarean section has an effect on their decision regarding the choice of anesthesia.
\end{abstract}

Material and Method: This study included 138 patients who were scheduled for elective cesarean section. The anesthesia type was chosen by patients. Patients were divided into two groups according to their choice: general anesthesia group $(n=63)$ and spinal anesthesia group ( $n=75)$. Beck Anxiety Inventory (BAI), Beck Depression Inventory (BDI) and Pain Catastrophizing Scale (PCS) questionnaires were completed to measure participants' psychological state. Patients were then assessed preoperatively, and demographic information was recorded.

Results: The BAI and PCS scores were significantly higher in the general anesthesia group according to the spinal anesthesia group ( $p<0.05)$. There was no difference between the two groups according to BDI ( $p>0.05)$.

Conclusion: Anxiety score was found high in patients who preferred general anesthesia. In these patients, anxiety-related measures (preoperative and postoperative period) should be taken.

Keywords: Anxiety, anesthesia, spinal, general, cesarean section
Öz

Amaç: Sezaryen doğum ile ilişkili maternal anksiyete önemli bir konudur. Elektif sezaryen hastaların preoperatif anksiyete düzeylerinin anestezi seçimine ilişkin kararlarını etkileyip etkilemediğini değerlendirmeyi amaçladık.

Gereç ve Yöntem: Bu çalışmaya elektif sezaryen planlanan 138 hasta alındı. Anestezi şekli hastalar tarafından seçildi. Hastalar seçimlerine göre iki gruba ayrıldı: genel anestezi grubu $(n=63)$ ve spinal anestez grubu ( $n=75$ ). Katılımcıların psikolojik durumunu ölçmek için Beck Anksiyete Envanteri (BAl), Beck Depresyon Envanteri (BDI) ve Ağr Felaket Ölçeği (PCS) anketleri dolduruldu. Hastalar preoperatif olarak değerlendirildi ve demografik bilgiler kaydedildi.

Bulgular: Genel anestezi grubunda BAI ve PCS skorları spinal anestezi grubuna göre anlamlı olarak yüksekti $(p<0,05)$. BDI'ya göre gruplar arasında fark yoktu $(p>0,05)$.

Sonuç: Genel anestezi tercih eden hastalarda anksiyete skoru yüksek bulundu. Bu hastalarda anksiyete ile ilgli önlemler (preoperatif ve postoperatif dönem) alınmalıdır .

Anahtar Kelimeler: Anksiyete, anestezi, spinal, genel, sezaryen

Corresponding (IIletişim): Hakan Tapar, Gaziosmanpasa University, Faculty of Medicine, Department of Anesthesiology and Reanimation, 60100 Tokat, TURKEY

E-mail (E-posta): hakantapar@hotmail.com

Received (Geliş Tarihi): 24.10.2019 Accepted (Kabul Tarihi): 05.07.2020 


\section{INTRODUCTION}

Cesarean section is a common surgical procedures on obstetric patients and it have been increasing throughout the world. In cesarean section, although general anesthesia has many advantages, such as better hemodynamic stability and faster induction, it also has complications, such as maternal intubation failure and neonatal depression due to anaesthetic drugs. 1 Therefore, general anesthesia is preferred in cases where emergency cesarean sections and regional anesthesia are contraindicated. Regional anesthesia compared to general anesthesia has advantages such as not requiring tracheal intubation, decreased risk of aspiration, less analgesic requirement and being awake. 2

Anxiety is a subjective emotion characterized by apprehension and fear of pain. The extent and type of surgery and preoperative information are potential factors affecting perioperative anxiety. Literature has reported a higher level of preoperative anxiety in obstetric patients compared to other surgical procedures. 3

Today, the choice of anesthesia depends on the experience of the anesthetist, the obstetric causes and the wishes of the patient. The rate of general anesthesia in patients who underwent caesarean section is $46 \%$ and patient's preference is the commonest reason for choosing general anesthesia. $4 \mathrm{In}$ the case of elective cesarean section patients who do not have medical necessity, we wanted to investigate whether anxiety is influential on the anesthesia preference of patients who will undergo elective cesarean section.

\section{MATERIAL AND METHOD}

After study approval was obtained from the Gaziosmanpasa University Clinical Research Ethics Committee (17-KAEK076), the study was registered at www.clinicaltrials.gov (NCT03213262). This study included 138 consecutive patients, who were scheduled for elective cesarean section between July 2017 and September 2017. The study was conducted in accordance with the Declaration of Helsinki. Pregnant women aged 18 to 40 years, scheduled for elective cesarean surgery and with American Society of Anesthesiologists physical status II (ASA II) were included in this prospective study. Exclusion criteria were non-elective surgery, psychiatric (basaline anxiety and depression) or neurologic disorder, obstetric complications including antepartum haemorrhage, contraindication for spinal anesthesia or general anesthesia. Written informed consent was obtained from all patients. The anesthesia type was chosen by patients. Patients were divided into two groups according to their choice:) general anesthesia group ( $n=63)$ and spinal anesthesia group $(n=75)$.

There are different methods for evaluating preoperative anxiety and depression, and we used Beck Anxiety Inventory (BAI) and Beck Depression Inventory (BDI) questionnaires in this study. $\mathrm{BAI}$ and $\mathrm{BDI}$ are rated on a 4-point scale ranging from 0 to 3 , and the total scores range from 0 to 63 . BAl score is interpreted to indicate minimal or no anxiety (range $0-9$ ), mild anxiety (10-18), moderate anxiety (19-29) and severe anxiety (30-63). BAI was developed as a measure for dividing between anxiety and depression. 5 Ulusoy et al. validated the Turkish version of this questionnaire. 6 It is used to obtain an assessment of anxiety independent of depression. $7 \mathrm{BDI}$ developed by Beck et al., is a 21-item self-reporting questionnaire for evaluating the severity of depression of an individual. 8 The BDI score is classified into minimal depression (range 0-13), mild depression (14-19), moderate depression (20-28) and severe depression (29-63). 9 The questionnaire used in this study was validated previously by Hisli. 10 The Pain Catastrophizing Scale (PCS), created by Sullivan et al., is used to measure the degree of individual pain catastrophizing and consisting of three subgroups (helplessness, magnification, and rumination). 11 Suren et al. validated the Turkish version of questionnaire. 12 We used these three questionnaires to assess the relationship between anxiety and anaesthesia preference.

An anaesthesiologist visited the patients one night before the surgery, gave information with written (standardized text explaining advantages/disadvantages of general versus regional anaesthesia) and verbal expressions about anaesthesia, and then asked to complete questionnaires including BAI, BDI and PCS. After being informed, patient's anaesthesia preferences were recorded in the surgical room at the operation day. This study was conducted by two experienced anesthesiologist.

The demographic information of both groups was recorded first. The anxiety levels of the general anaesthesia and spinal anaesthesia groups were evaluated with BAI, BDIs and PCSs in the preoperative period.

\section{Statistical analysis}

A total of 138 participants was required to find a significant difference after calculating the sample size using the formula ' $n=t 2 . p . q / d 2$ ', where $t$ was 1.96 with a degree of freedom of 0.05 . p was accepted as an estimated value of $10 \%$, in which anxiety affected the anaesthesia type; q was accepted as an estimated value of $90 \%$, in which anxiety did not affect the anaesthesia type. $d$, the type 1 error, was accepted as 0.05 .

Descriptive data were presented as mean $( \pm S D)$ for the continuous variables, median (range) for the ordinal variables, and numbers (frequencies) for the categorical variables. The one-sample Kolmogorov-Smirnov test was used to assess the normality of the distribution. Independent samples t-tests were used to compare data among groups. All statistical analyses were performed using Statistical Package for the Social Sciences (SPSS) software version 20.0 (SPSS Inc., Chicago, IL, USA). $\mathrm{p}$ - value less than 0.05 was considered statistically significant. 


\section{RESULTS}

A total of 138 participants undergoing cesarean section were evaluated in this study: 63 with general anesthesia and 75 with spinal anesthesia. The socio demographic characteristics of the respondents are shown in Table 1. The mean age of participants with general anesthesia was $29.88 \pm 4.76$, while the mean age for participants with spinal anaesthesia was $30.17 \pm 5.22(p=0.73)$. When the education levels, pregnancy weeks, previous surgery, number of pregnancies of the groups were examined, no statistical difference was found between the groups ( $p>0.05)$.

Table 1. Preoperative anxiety in patients selecting either general or spina anesthesia for elective cesarean section

\begin{tabular}{lccc} 
& $\begin{array}{c}\text { General } \\
\text { anesthesia }\end{array}$ & $\begin{array}{c}\text { Spinal } \\
\text { anesthesia }\end{array}$ & p \\
\hline Age & $29.88 \pm 4.76$ & $30.17 \pm 5.22$ & 0.73 \\
Pregnancy weeks & $37.12 \pm 1.30$ & $37.26 \pm 0.97$ & 0.45 \\
Previous surgery & & & \\
Obstetric & 43 & 42 & 0.51 \\
Non-obstetric & 3 & 8 & 0.61 \\
None & 17 & 25 & 0.59 \\
Number of pregnancies & $3.2 \pm 2.1$ & $4.1 \pm 1.9$ & 0.27 \\
Education of level & & & \\
Matric and below matric & 8 & 11 & 0.49 \\
Intermediate & 27 & 28 & 0.40 \\
Graduate & 28 & 36 & 0.42 \\
\hline
\end{tabular}

$\mathrm{BAI}, \mathrm{BDI}$ and PCS results according to different anesthesia types were presented in Figure 1,2,3. The mean BAI value was found to be $18.12 \pm 10.41$ in patients preferring to undergo general anesthesia and $13.92 \pm 9.05$ in patients preferring to undergo spinal anesthesia $(p=0.013)$ (Figure 1). The mean BDI value was found to be $10.17 \pm 6.67$ in the general anesthesia group and $8.74 \pm 8.00$ in the spinal anesthesia group $(p=0.255)$ (Figure 2). The mean PCS values of the groups were $23.58 \pm 12.93$ in the general anesthesia group and $19.25 \pm 11.19$ in the spinal anesthesia group $(p=0.039)$ (Figure 3$)$.

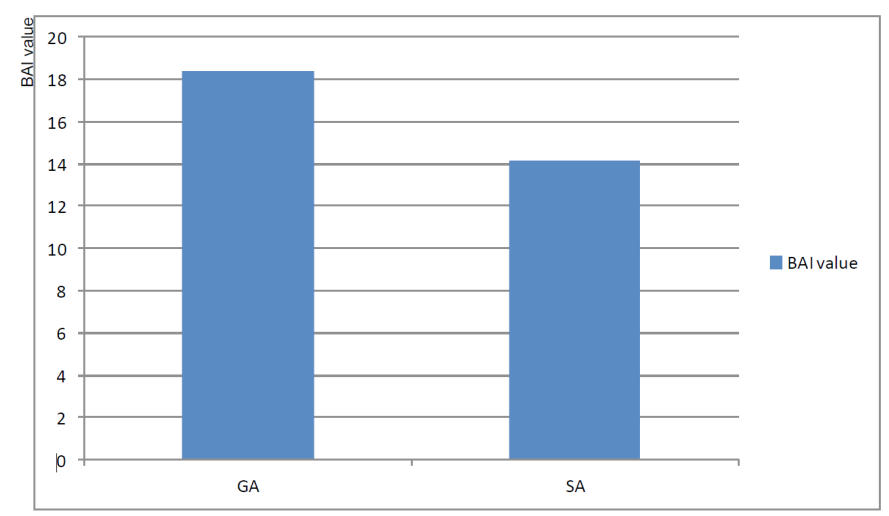

Figure 1. Mean BAI values of the groups

GA, general anesthesia; SA, spinal anesthesia; BAI, Beck Anxiety Inventory. Independent samples t test. $\mathrm{p}=0.013$.

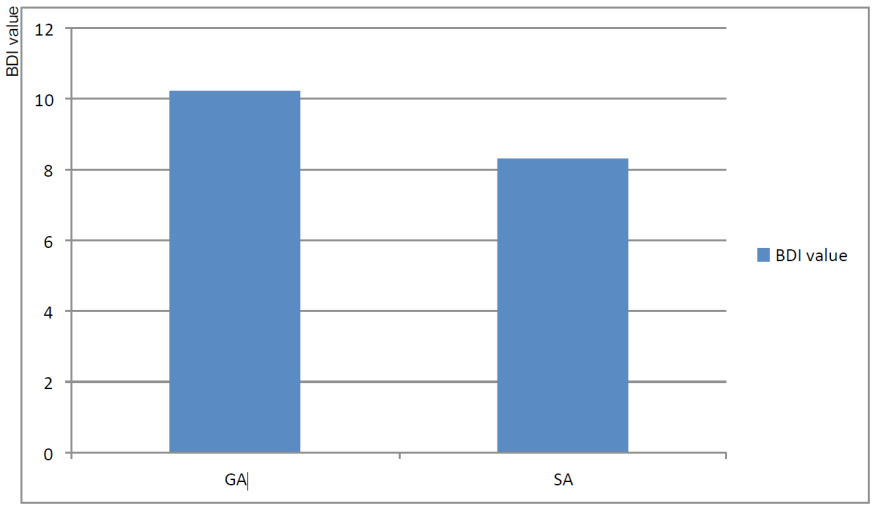

Figure 2. Mean BDI values of the groups

$\mathrm{GA}$, general anesthesia; SA, spinal anesthesia; BDI, Beck Depression Inventory.

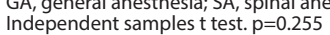

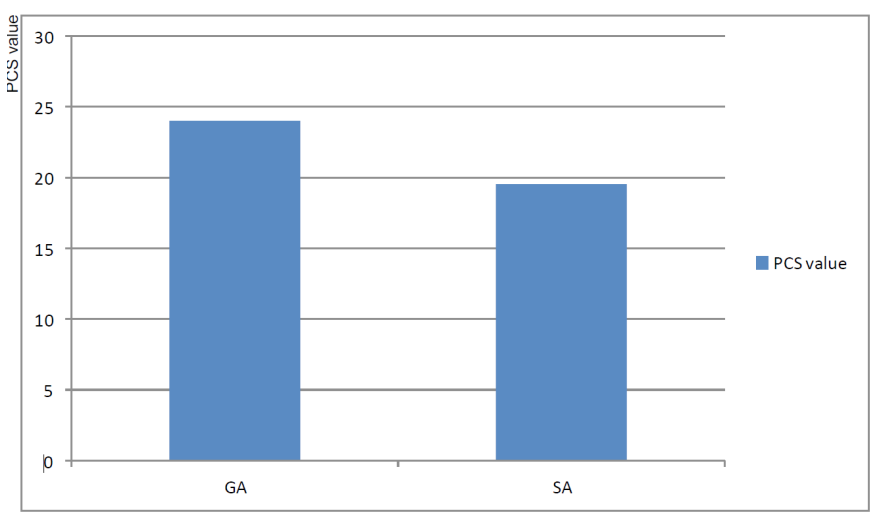

Figure 3. Mean PCS values of the groups

GA, general anesthesia; SA, spinal anesthesia; PCS, Pain Catastrophizing Scale. Independent samples t test. $\mathrm{p}=0.039$

\section{DISCUSSION}

In this study, we determined that anxiety is influential in general anesthesia preference, demonstrated by the level of preoperative maternal anxiety in patients undergoing elective cesarean section and its significant association with the chosen anesthesia.

Anxiety present in patients in the preoperative period is due to many causes. Personality traits or surgical and anesthetic concerns may induce anxiety. Studies that investigated anxiety levels in the preoperative period found that the incidence of preoperative anxiety ranges from $60 \%$ to $80 \% .13$

Surgery is a stressful process, even for people without anxiety disorders, as patients are confronted with the possibility of pain, loss of power or death. 14 Although there are studies to measure the preoperative anxiety level and to elucidate its causes 15, there are very few studies investigating the level of preoperative anxiety regarding general and spinal anesthesia. In the study conducted by Akyildiz et al., the level of anxiety was higher in patients who underwent spinal anesthesia. 16 In this study, no meaningful reason was explained to explain the difference between the groups. However, a study performed by Maheshwari et al. showed that patients who preferred general anesthesia rather than regional anesthesia had higher anxiety level. This study demonstrated that the rate of anxiety was 
found $61.60 \%$ and $38.40 \%$ in general and regional anesthesia, respectively. 17 This difference was associated with informing patients in the GA group by non-anesthesiologists. The BAI level of patients who chose general anesthesia was higher than the ones who chose spinal anesthesia in our study.

The BDI can be attributed to the medical illness (e.g. difficulties with concentration and fatigue). 18 In this study, there was no difference between the general and spinal anaesthesia groups when they were evaluated according to $\mathrm{BDI}$, and the $\mathrm{BDI}$ values of the two groups were interpreted as minimal range.

Investigation of the relation between anxiety, pain of fear of pain is very complex. A study performed by Martin et al. found that anxiety sensitivity is the only major predictor of fear of pain after the exception of sex and age. 19 Furthermore, pain catastrophizing, a negative mental state emerging during an actual or anticipated painful experience, is one of the psychological predictors of pain. 20 Pain catastrophizing contains fear of pain, pain helplessness and negative thoughts such as depression, anxiety and worry. Higher values show greater catastrophizing. 21 As mentioned previously, fear of pain correlates with anxiety which closely associated with pain catastrophizing. In our study, the PCS score was found higher in patients received general anesthesia compared to spinal anesthesia. This outcome confirmed the higher anxiety levels in patients with general anesthesia.

Surgery and anesthesia may provoke more fear and worry in women with pregnancy whose planned to undergo cesarean section. The most common reason for choosing general anesthesia is fear of being awake during spinal anesthesia. 22 A study conducted in pregnant women undergoing cesarean section in Nigeria found that reasons for refusal of regional anesthesia included fear of seeing or hearing during surgery and fear of needle placement. 23 In the same study conducted by Bukar et al., caesarean section patients mostly preferred general anesthesia, and fear of being awake, anxiety, wants to be asleep, do not want to feel pain, fear of nightmares and do not even want to see the theatre were the most common reasons. In the similar study, patients that want to know what is going on and fear of not waking up from general anesthesia were shown as some reasons for preference of regional anesthesia. 24 In this context, women with pregnancy would prefer general anesthesia to avoid their fear and worry about surgery and anesthesia, however the choice of regional anesthesia is associated with their curiosity. In relation, the higher anxiety and pain catastrophizing levels in women with pregnancy underwent general anesthesia suggested the same conclusion as indicated by Bukar et al. that fear and worry could be the trigger point for this outcome.

\section{Limitations of the study}

This study has some limitations. First, the general anxiety and depression scores of the patients were examined, however predisposing factors for anxiety were not evaluated. Second, the population of the study was selected from a local area which restricts the generalizability of the study outcomes.

\section{CONCLUSION}

This study revealed that the anxiety level is higher in patients who prefer general anesthesia or anxiety is one of the reasons for refusing regional anesthesia. This can be especially considered in the follow-up of patients preferring general anesthesia. Preoperative visual and written information may help assist in the fight against anxiety and in making regarding their choice of anesthesia technique.

\section{ETHICAL DECLARATIONS}

Ethics Committee Approval: After study approval was obtained from the Gaziosmanpasa University Clinical Research Ethics Committee (17-KAEK-076), the study was registered at www.clinicaltrials.gov (NCT03213262).

Informed Consent: All patients signed the free and informed consent form.

Referee Evaluation Process: Externally peer-reviewed.

Conflict of Interest Statement: The authors have no conflicts of interest to declare.

Financial Disclosure: The authors declared that this study has received no financial support.

Author Contributions: All of the authors declare that they have all participated in the design, execution, and analysis of the paper, and that they have approved the final version.

Note: This article was presented in the International Hippocrates Congress on Medical and Health Sciences, Turkey on 1-3 March 2019 as oral presentation.

\section{REFERENCES}

1. Tsen LC. Anesthesia for cesarean section. In: Chestnut DH, Polley LS, Wong CA, Tsen LC, editors. Chestnut's obstetric anesthesia: principles and practice. 4th ed. Philadelphia: Elsevier Mosby. 2009;521-51.

2. Liu SS, Strodtbeck WM, Richman JM, Wu CL. A comparison of regional vs general anaesthesia for ambulatory anaesthesia: a meta-analysis of randomized controlled trials. Anaesth Analg 2005;101:1634-42.

3. Jafar MF, Khan FA. Frequency of preoperative anxiety in Pakistani surgical patients. J Pak Med Assoc 2009;59:359-63.

4. Ismail S, Shafiq F, Malik A. Technique of anaesthesia for different grades of caesarean section: A cross-sectional study. J Pak Med Assoc 2012;62:3637.

5. Beck AT, Epstein N, Brown G, Steer RA. An inventory for measuring clinical anxiety:

6. psychometric properties. J Consult Clin Psychol 1988;56:893-7.

7. Ulusoy $M$, Şahin $N$, Erkmen $H$. Turkish version of the beck anxiety inventory: psychometric properties. J Cognitive Psychotherapy: Int Quarterly 1998;12:28-35.

8. Julian LJ. Measures of anxiety: State-Trait Anxiety Inventory (STAI), Beck Anxiety Inventory (BAI), and Hospital Anxiety and Depression ScaleAnxiety (HADS-A). Arthritis Care Res 2011;63:467-72.

9. Steer RA, Beck AT, Garrison B. Applications of the Beck Depression Inventory. In: Sartorius n, Ban TA, eds. Assessment of Depression. Geneva, Switzerland: World Health Organization. 1986;121-42. 
10. Jackson-Koku G. Beck Depression Inventory. Occup Med 2016;66:174-5.

11.1Hisli N. Beck Depresyon envanterinin üniversite öğrencileri için geçerliliği, güvenilirliği. Psikoloji derg 1989;7:3-13.

12. Sullivan MJ, Bishop SR, Pivik J. The pain catastrophizing scale development and validation. Psychol Assess 1995;7:524-32.

13. Süren M, Okan I, Gökbakan AM, et al. Factors associated with the pain catastrophizing scale and validation in a sample of the Turkish population. Turk J Med Sci 2014;44:104-8.

14. Pokharel K, Bhattarai B, Tripathi M, Khatiwada S, Subedi A. Nepalese patients' anxiety and concerns before surgery. J Clin Anesth 2011;23:3728.

15. Colon EA, Popkin MK. Anxiety and Panic. in: J.R Rundell, M.G Wise (Eds.) Textbook of Consultation Liaison Psychiatry. American Psychiatric Press, Washington DC;1996:402-25.

16. Kain ZN, Wang SM, Caramico LA, Hofstadter M, Mayes LC. Parental desire for perioperative information and informed consent: A two-phase study. Anesth Analg 1997;84:299-306.

17. Akyildiz M, Aksoy Y, Kaydu A, Kıvılcım Kaçar C, Fatih Şahin Ö, Baysal Yıldııım Z. Effect of anaesthesia method on preoperative anxiety level in elective caesarean section surgeries. Turk J Anaesthesiol Reanim 2017;45:36-40.

18. Maheshwari D, Ismail S. Preoperative anxiety in patients selecting either general or regional anesthesia for elective cesarean section. J Anaesthesiol Clin Pharmacol 2015;31:196-200.

19. Lee EH, Lee SJ, Hwang ST, Kim JH. Reliability and validity of the Beck Depression Inventory-II among Korean Adolescents. Psychatry Investig 2017; 14:30-6.

20. Bedaso A, Ayalew M. Preoperative anxiety among adult patients undergoing elective surgery: a prospective survey at a general hospital in Ethiopia. Patient Saf Surg 2019;13:18.

21. Ulvers $\mathrm{K}$, Hood A. The role of positive traits and pain catastrophizing in pain perception. Curr Pain Headache Rep 2013;17:330.

22. Hirsh AT, George SZ, Riley JL III, Robinson M. An evaluation of the measurement of pain catastrophizing by the coping strategies questionnaire. Eur J Pain 2007;11:75-81.

23. Senel AC, Mergan F. Premedication with midazolam prior to caesarean section has no neonatal adverse effects. Braz J Anesthesiol 2014;64:16-21.

24. Bukar M, Kwari DY, Moruppa JY, Ndonya DN. Anaesthesia for caesarean delivery: Choice of technique among antenatal attendees in North Eastern Nigeria. J Obstetr Gynecol 2010;30:822-5.

25. Gajraj NM, Shazma SK, Souter AJ, Pole Y, Sidawi JE. A survey of obstetricpatients who refuse regional anaesthesia. Anaesthesia 1995;50:740-1. 